\title{
MODEL OF TRAINING SOFT SKILLS FOR NURSES IN MANAGING STRESS IN PATIENTS AT THE HOSPITAL
}

\author{
Nentien Destri \\ Prodi D-III Keperawatan,STIKes Yarsi Sumbar \\ Padang, Indonesia \\ email: sagitanendri lgf@yahoo.co.id \\ Lufri \\ Fakultas MIPA, Universitas Negeri Padang \\ Padang, Indonesia
}

\author{
Mukhaiyar \\ Fakultas Bahasa Inggris, Universitas Negeri Padang \\ Padang, Indonesia \\ Menkher Manjas \\ Fakultas Kedokteran, Universitas Andalas Padang \\ Padang, Indonesia
}

\begin{abstract}
This study was conducted as long as the nurses do not fully implement the elements of soft skills in performing nursing care, particularly in the management of stress in patients in the hospital.To overcome this problem, the researcher developed a model Training Soft Skills for nurses in an effort to improve the intrapersonal and interpersonal competence of the nurses in the management of stress on the patient. The type of research is developmental of research. The development model used is a model presented by Sugiyono (2010). The data were collected through discussions, observasing, interviews, questionnaires and learning test sheet. The data collected were analyzed using descriptive statistics and statistical inference. Based on the stages of the development process and the implementation of product testing to nurses 14 people, it was found that the product is very valid, very practical, and effective to implemented in hospitals. After several revisions as suggested byadvisors, the product of research as expected, the development of the training model, could exist. The model produced, Book I a book as a guide to the model, Book 2 is the facilitator's guides, and Book 3 is guide by a trainees. Materials are considered valid by the validator expert is a model oftraining soft skills in stress management. So soft skills training models for nurses in the management of stress in patients fit for use after rated valid, practical and effective.
\end{abstract}

Keyword : Soft skills, nurses, managing stress

\section{INTRODUCTION}

Soft skills is the competence to organize themselves properly and the ability to build relation effectively. Self-managing competence is called intrapersonal skills, while the ability to build relation is called interpersonal skills (Muqowin, 2012). Directorate General of Higher Education (2008) said "Hard skills is the mastering of science, technology, and technical skill that relate to the field of knowledge. If each profession demands to have different science, not so for soft skills, because this skill should be owned by everybody.

Hospital as an organization needs to notice the important aspects which influence the quality of service to everyone as one of crucial indicators in fulfill the needs of users especially patients and most service providers, nurse.

The relationship of nurse and patient are established in nursing care activity in the form of nursing process. Nurse competence could be done through intrapersonal skill and interpersonal skill which is called soft skills.
Ability required is not only in hard skill, soft skill also has important role, mainly mental disease disorder. Soft skill guidance for nurse to handle patient stress needs be done effectively so that the service can overcome their stress. If it does not handled immediately and not managing well the stress can impacts variety of illnesses, somatik disorder, health disorder, and social disorder. Long stress can cause the reduction of patient body endure.

\section{Formulation of Problem}

Formulation of problem is how are the validation, practicality, and effectiveness from soft skill training for the nurse in order to manage the stress of patients in the hospital.

\section{Purpose of the Research}

Based on the background and formulation of problem above the purpose of the research is to produce soft skill training model which is valid, practical, effective for the nurses in order to manage patients stress in the hospital. 


\section{The Advantages of Model}

This development research produces three guidebooks that are useful in the soft skill training for the nurses in order to manage patients stress in the hospital. The first book will provides the soft skill and managing stress, the second book is used by interviewees or instructors at the training, and the third book is a guide for the nurses in order to soft skills implementation.

\section{REVEW OF RELATED LITERATURE}

\section{Soft Skills Theory}

Muqowin (2012) said "Soft skills is the competence to organize themselves properly and the ability to build relation effectively. Self-managing competence is called intra-personal skills, while the ability to build relation is called interpersonal skills".

Soft skills is divided into interpersonal skills and intrapersonal skill;

a. Interpersonal Skills

According to Elfindri and friends (2009: 81-82) interpersonal skill is communication ability, forming the team working, the ability to work in team, being trained in work ethic, and flexible in work.1) Communication ability; good communication is delivered with intonation, and feeling so that the other person is easy to follow the thought and delivered without offended others. 2) There is team working; the habit to work together should be trained because it is impossible to work alone. 3) Trained for work ethic; talent to keep a secret suitable with work commitment, have a good manner. 4) Flexible to do the job; able to do the work even though not many people like it, do not select the work.

\section{b. Intrapersonal Skills}

According to Elfendri and friends (2009:82-83) to be able to train intrapersonal ability are 1) Polite and natural appearance; hospital workers should look after their appearance to be accepted by the locals. Clothes and appearance should be in the right way so that the inner beauty could appear nicely. 2) Realize the important of self cleanliness; personal hygienic is the main modal for the health workers start from nail, tooth, hair and many others. The tradition to protect the foods and sports are the modal of self cleanliness. 3) Capable to rule the time and income; on time and keep the promise are modal to work. 4) Follow the era development; read the books of your own specification to get easy see the future. 5) Skill of hearing patiently; used to know others prospective, be wise, fit with the time, place and condition and try to keep emotional.

\section{RESEARCH METHODOLOGY}

\section{Type of Research}

The type of the research was research and development ( $\mathrm{R} \& \mathrm{D})$. The purpose was to obtain soft skills training model in order to manage patients stress in the hospital. The development was done by the steps of research and development methodology that was showed by Sugiyono who said (2010) "Research methodology uses to produce a product, and to examine the effectiveness of it".

\section{Development Model}

The research was to discover Soft Skills training model for the nurses in order to manage patients stress in the hospital, that used procedural model. Prawiradilaga (2007) said, "Descriptive model outlined the steps that should be followed to produce a product". The modeling was tailored to the steps taken sequentially. This model helped researcher produced a valid, practical, and effective product.

The components of the model were limited to; Soft Skills training model for the nurses in identifying the causes of stress in patients, performing relaxation to the patients, and determining therapeutic measures to the patients.

\section{Research Procedure}

The research used the steps proposed Sugiyono (2010) can be passed by stages; 1) potential description and problem, 2) data collection, 3) model design, 4) FGD, 5) revision model by researcher, 6) validation model, 7) revision model by researcher, 8) test model, 8) trial usage, 9) revision model by researcher and 10) model produced.

\section{RESEARCH FINDINGS AND DISCUSSION}

The Islamic Hospital of Ibnu Sina Bukittinggi, which was located in the center of Bukittinggi, was a private hospital owned by Muslims with 136 treatments capacity. The vision was to actualize the Islamic Hospital of Ibnu Sina Bukittinggi becomes type B hospital in the year 2020. Hence, the missions consisted of; a) performing excellent service, b) equipping resource, c) enhancing professionalism, d) establishing cooperation with related institution, and e) applying islamic values in providing services. 


\section{Development Results} following:

The development of results were in the

\section{Potential and Problem Descriptions}

Potentials that could be seen in The Islamic Hospital of Ibnu Sina Bukittinggi were: a) Human Resources were permanent employee, 360 persons; medical personnel, Nursing staff, non-nursing health care, non medical or general personnel. While b) the number of nurses were 152 persons. In the table, 140 nurses $(92,1 \%)$ experienced more than 2 years of work experience, while the most nurses were D3 level of education, 141 persons $(92,8 \%)$.

\section{Data Collections}

Data were collected in order to obtain preliminary data as well as the necessary information as a basis for the model: a) The stress level in patients was obtained through the DASS 42 to all patients in total population of 48 people in the Surgery, Interne, and Midwife Room. There were no significant levels of stress and panic, those generally were at mid level of 26 (53.1\%). A total of 17 people $(34.8 \%)$ experienced mild stress in Mid wifery Room and in the Interne Room only $4(8.2 \%)$.

Management of stress that researcher got through; observation, interview, and documentation. a) observations result found that during the communication the nurses only asked about the current condition of the patient, informed the nursing actions, and said to the patients if there was something needed, contact the nurses immediately. There was no data about nurses who asked the patients' stress condition, b) the result of the interview found that the nurses were strange with soft skill terminology so that they were less able to define soft skill. Nurses interviewed said: (1) "I have never done any specific identification to know whether a patient is experienced stress during treatment", (2) "I do the sress management according to my knowledge, I only give the therapies advice, such as finish the food served, take the medicine given, rest and obey the hospital rules". (3) "I do not know whether the implementation of my nursing actions toward the patients are already using soft skills or not", (4) "I do not have any protap on the application of the soft skills model in management of stress in patients". c) Documentation study result did not find or standard operating procedure (SOP) used in the patients stress management. SOPs that uses soft skills did not exist, whether for administrative, general, medical, midwife, or other health personnel.

The information of soft skills implementation by the nurses in stress management could be seen through research questionnaire as in the following:
Table 4.1

Implementation of Soft Skills Stress Management by Nurse in The Islamic Hospital of Ibnu Sina Bukittinggi

\begin{tabular}{|c|c|c|c|c|c|c|c|}
\hline No & \multirow{2}{*}{$\begin{array}{c}\text { Implem } \\
\text { entation } \\
\text { Criteria }\end{array}$} & \multicolumn{2}{|c|}{ Soft Skills Implementation } & \multicolumn{2}{c|}{ Total } \\
\cline { 3 - 8 } & $\begin{array}{c}\text { Interpersonal } \\
\text { Skill }\end{array}$ & $\%$ & $\begin{array}{c}\text { Intrapersonal } \\
\text { Skill }\end{array}$ & $\%$ & Soft skills & $\%$ \\
\hline 1 & $\begin{array}{c}\text { Very } \\
\text { Good }\end{array}$ & - & & 1 & 2,6 & - & - \\
\hline 2 & Good & 27 & 71 & 19 & 50 & 25 & 65,8 \\
\hline 3 & Average & 11 & 29 & 18 & 47,4 & 13 & 34,2 \\
\hline 4 & Poor & - & - & - & - & 0 & 0 \\
\hline 5 & $\begin{array}{c}\text { Very } \\
\text { Poor }\end{array}$ & - & - & - & - & 0 & 0 \\
\hline
\end{tabular}

Based on the table above from 38 nurses in The Islamic Hospital of Ibnu Sina Bukittinggi was found that $65,8 \%$ nurses applied soft skills very well, $71 \%$ nurses did interpersonal skill in good category, while intrapersonal skill $50 \%$ of nurses did good stress management.

\section{Model Design}

In this stage, there was a development to design the model of soft skills training for the nurses in obtain the stress to the patients by determined the properly aspects based on the needs through the process of; a) Deciding soft skills components in the research; intrapersonal and interpersonal skills. Intrapersonal skill; polite and natural; maintain personal hygiene; personal hygienic is the main model and the most important intrapersonal factor for health personnel; capable to manage the time; skillful in listening and be patient.

Interpersonal skill; nurse skill in communicating; teamwork among fellow nurses and/or other medical personnel, trained in work ethics, adapted to pledges and promises that pronounced at the time of the nurse's oath. The nurse considers the rights and duties of the patient, in addition to what their rights and duties are as professional vocation nurses and professional nurses and flexible performs the work.

Established stress management activities. The following were the theories than can be done in managing stress that experienced by a person; Identified the causes of stress, relaxation techniques, and overcame the causes of stress.

In order to improve the soft skills of the nurses in managing stress on the patient, the hospital needed to require special attention and developed planning in order to develop the capability. One of that plans was nursing training. This development research would produce the product in the form of soft skills training model for nurses in patient stress management. This model was determined after previously defined skill sets, whereby 
nurses were required to have soft skill in managing patients, intrapersonal and interpersonal skills, so that the basic development in patient management, especially stress management, could be used.

In the design of model would explain how a model of soft skills training in the management of patient stress. The developed model was presented in the form of guidebooks with the stages of preparation as follow: the establishment of guidebook cover, the type of manual that was Book 1: Model Guide, Training Model Soft Skill for Nurses in Stress Management for the patients. Book 2: Resource Guide/Facilitator's Guide, and Book 3: Guide for soft skills participants for Nurses in Patient Stress Management.

\section{Focus Group Discussion (FGD)}

Focus Group Discussion (FGD) is a focused discussion activity. At the time of FGD implementation, researcher obtained many inputs that used as a consideration in revising the model that was designed. FGD were conducted in accordance with the agreement of promoter team and experts related to the research on the Soft Skills Training Model for Nurses in Management of Patient Stress in the Hospital.

\section{Revised Model Design}

The inputs that received during FGD were very important reference for the researcher in improving the development of soft skills training model for nurses in managing the patient stress. The researcher revised systematically in accordance with the suggestions and inputs provided by the experts during the FGD process.

\section{Design Model Validation by expert}

The purpose of validation was to examine the corrections of concepts and grammar in the model that has been designed. Validation of products was done by presenting some experts who were experienced for new products designed (Sugiyono, 2011). Each expert assessed the design, so that the weaknesses and advantages were known.

Assessment that was given by validators on the development of soft skills model in management of patient stress. From the instrument validation result with general assessment by the experts concluded that instrument validation model that have been designed could be used with small revision (Category B). The instrument was validated to the model by the same expert, it was done at the revision stage of research design.

\section{Experiment Model}

Trials were conducted to determine the practicality and effectiveness of the soft skills training model in patient stress management. The trials were conducted on limited groups, at different locations. Based on certain considerations, the location is estimated to have the same characteristics with the hospital environment, the researcher conducted a test at the Health Science Academy (STIKes) Yarsi Bukittinggi because the researcher is a lecturer at this institution and obtained permission from the head of the college.

The experimental model was conducted on the sample by $10 \%$ of the total nurses so that 15 nurses who served in Ibnu Sina Bukittinggi Hospital were chosen. The activity had been conducted for 2 (two) days attended by 14 (fourteen) nurses. It was conducted in the form of training for nurses in applying the model. Researcher invited practitioners who provided material during the learning process.

The result of the experiment showed that the percentage of nurses response to the model that had been tested was $93.9 \%$, thus the model was very practical to be used in managing the patients stress in the hospital. Through this model the nurses could familiarize their selves to manage their patients stress. This model can be used systematically because it has been designed with clear stages. Nurses will try to use this model while on duty to serve patients in the hospital.

Patients response in applying model showed that it was practical. The practical response was $85.7 \%$ to $92.9 \%$ (Very practical). This percentage explained the soft skills training model was effective to the nurses in managing the patients stress in the hospital. Implementation of the model according to the patients was very practical, that was $90,7 \%$. By this model the nurses could spend much time with the patients.

Data Description of Model Effectiveness. The improving ability of nurses in implemented the model that had designed would show whether the model was effective or not. In the first day of trial there was a pretest to find out the nurses knowledge about basic concept of soft skills, basic concept of stress including stress management, then in group the nurses discussed their understanding based on the questions that given to them.

After the classical material was given, there was another evaluation of the same problem in the form of post test. Researcher performed data processing manually to find out the evaluation results obtained by the nurses. Evaluation results explained that the score obtained by nurses before the coaching was $46.4 \%$ to $66 \%$. After the material was given, the result of the evaluation obtained by the nurses was $71.4 \%$ until $83.9 \%$, that was good and very good categories. These results showed that through this model the nurses could improve their competence in order to serve their patients.

Before the soft skills material was given, the knowledge of nurses were 26 (46.4\%) which belonged to enough category, after the material was given by the post test, the nurses got the value of $45(80.4 \%)$ which belonged to good category and the average category from all components evaluated, the value of $32(57.1 \%)$ from enough category increased to $45(80.4 \%)$ with good category, it means there was increasing understanding of 
nurses about soft skills so that this model can be said effective to be applied in managing stress for patients in the hospital.

The next test was done with statistical tests, because there were only 10 items of questions and 14 respondents. The average value of effectiveness analysis before model development in the figure above is 31.7 with a standard deviation of 3.199. While the mean effectiveness of the problem after the development of the model is 44.9 with a standard deviation of 2.601. The difference of questions effectiveness before and after model development are 13.20. The result of statistical test obtained $\mathrm{p}=0.005$ can be concluded that there is difference of effectiveness value between before and after model development.

\section{Model Revision}

Based on the experiment analysis above, in principle it does not need to be revised again, because it has been clearly known the validity, practicality, and effectiveness of the model. However, researcher continued this revision by improving the parts related to writing, grammar, and typing. Revisions were made through the guidance of the promoter team so that the results of this study were accepted by the team.

\section{Soft Skills Training Model in Managing the Patients Stress in the Hospital}

Model that had been tested and revised would be determined as a result of research called the Soft Skill Training Model in the management of stress for patients in the hospital.

\section{DISCUSSION}

The discussion is directed based on the purpose of research development of soft skills training model for nurses in the management of stress for patients in the hospital. Book 1 is designed to provide a general overview of the training model developed, furthermore in Book 2 the researcher describes the training method that will be used by the resource person/facilitator in using soft skills training in stress management for the patients. In Book 3, the nurse's guides outlined in detail the nurse will take during a soft skills training in the management of stress for the patients in the hospital.

The designed training model has been revised in accordance with the advice and validation of the experts, and then asked for suggestions from practitioners from nursing organizations, from health education, psychologists and community leaders. The model has been improved in accordance with the advice given, in terms of the format, method, and content of the model. Model that have been validated and improved based on suggestions input various parties, then it has been tested to nurses from several hospitals located in Bukittinggi.

The result of soft skills training development model could be seen from practicality and effectiveness that obtained based on analysis of experiment model.

1. Validity based on experts validation toward the design of soft skills training model in the management of stress for the patients

Table 4.5 explains that model developed is valid and could be used with small revision. The average value that give by validators was 4.9 . It could be said that the model has been appropriated with the purpose of this development research. Trianto (2010: 255) said "Valid means it has been given accurate information about the media that is developing", it means this developed model can be justified because it has been asessed by the experts..

The developed model has described all the activities to be performed, evidence by 5 rating of validators with a very valid category so that the model is feasible to use. The supporting theories that exist in the model according to the experts are categorized so valid that the nurses will easily master the concepts theory that are given, and will have a positive impact on nursing services performed to patients and this model is very valid because it describes full activity information at each stage.

Researcher has completed the development of the model by meeting the construction requirements of a model. Using sentences correctly, the use of simple words, clear and easy to understand by the nurses. Sudjono (2011:166) said that the validation of construction can be interpreted as the validity seen from the composition, framework or fancies. Researcher has also tried technically to improve the development of the model, where the presentation of the model shown in communicative so easy to follow.

2. Practicality based on the nurse's response in the development of the soft skill model in stress management for the patients

The result of the study showed that the percentage of nurses response to the model that had been tested was $93.9 \%$ (very practical category) so that the model which had been arranged according to the nurse was very practical to be used in stress management for the patients in the hospital.

Nurses said the development of soft skills models is very practical to use ; 1) The development of the model facilitates the nurse in performing nursing care, 2) The use of the model can increase thenurse's motivation to familiarize themselves in implementing the model, 3) The application of the model to facilitate the nurses in performing soft skills , 4) Stages arranged in the model the nurse in applying it to the patient, 5) The description found at each stage of the model implementation makes it easy 
for the nurse to meet the needs felt by the patient, 6) The nurse finds an alternative to problem solving easily and quickly and 7) Visualization model in the form of images facilitate the nurse performs stress management for the patients in the hospital.

Professional nurses are not only seen from the ability to maintain and treat patients but also how they are able to provide comprehensive services from the aspects of biological, psychological, social, and spiritual vigorously accompanied by a smile and sincere heart (Mubarak, 2005: 74)

Nurses ability to follow the learning process is also very crucial, Suprijanto (2007: 44) said several factors that affect adult when he was in learning situations are internal factors such as age, hearing, and sight, while the external factor derived from the environment can be physical factors and non-physical factors. Nurses should maximize their ability so that they can follow the learning process very well and achieve the expected goals.

Stress management is done based on the opinions conveyed by Munith \& Nasir (2011: 97-100): a) Identify the factors of stress by understanding the causes and recognizing them before occur, understand the patient's stress level. B) Nurses can set time and resources to achieve the goals that want to achieve. C) Make a change by organizing the patient's room and encouraging the family to keep it neat, or the nurse can turn on the music that make the patient feel more comfortable. D) the nurse try to give the patient opportunity to be open about thoughts and feelings with himself and others, this is an effective technique for reducing stress. E) Talking with trusted people is one of the suggestions that nurses can give to their patients. F) Relaxation, to produce responses that can overcome stress response. Relaxation techniques affect the level of stress.

Nursing service is a professional integral part of health service which is based on the science and tips of nursing aimed at individual, family, group, or society, both healthy and ill (Kemenkes RI, 2015). The nurse's ability to manage the patient comprehensively is a competency that needs to be improved, the nurses are required to know the progress of the patient's disease, the nurse is able to empathize with the patient's condition by making them calm and comfortable, and the nurse must be skillful in managing their patient in various conditions, one of them is patients' stress. In addition, Effendy said nurses can be a place to ask questions for clients either individually, family, group, or community to solve various problems in the field of health and nursing.

Based on the theories, there are three things that will be used in the management of stress in patients: 1) identify the causes of stress, 2) relaxation techniques, 3) overcome the causes of stress. Those three things would get the expected results if those are done with soft skills. Chen (2012: xi) says that in fostering human relationships we need to understand people and human nature appropriately; understand their behavior, knows why and how to react in certain circumstances, and how we can manage relationships between the people.

The nurse, who is polite and candid, is a health worker, who is able to maintain the appearance of self, to be accepted by the local culture. Dress up, look, and self-directed, so that the dazzling inner beauty appear. Maintaining personal hygiene in this case is the main capital for health workers, ranging from clean nails, teeth, hair, and many others. The habit of taking care of food and exercise at the same time can be used as capital to maintain personal hygiene. Being skilled at arranging a nurse's time should be on time at work, and keeping the promise is the modal for us to work. In addition, nurses also have patience listening skills. Patience listening skills; accustomed to understand the intentions of others speak, respond wisely, according to time, place and conditions while maintaining emotional response.

The nurse has a role to play as an educator (Health Educator), so there are several competencies that must be improved. The soft skills of the nurse should be improved maximally so that the hard skills, they have acquired during the lecture, are more well realized. Through psychomotor knowledge and skills, nurses who have a good attitude, will easily apply their soft skills at the time of nursing care, especially in managing stress experienced by patients in the hospital.

3. Practicality based on patient response in the implementation of Soft Skills training model in stress management for the patients.

The results of the research, according to the the patient's opinion, showed that the model was very practical that was $90.7 \%$. Questionnaires results of the , the patient conveyed that the application of the model fits perfectly with the expectations of the patients as they can motivate them in getting solutions to the problems they are experiencing during treatment. The development of soft skills model was very practical for nurses in the management of stress for the patients in the hospital and facilitated nurses in doing nursing care to patients. 1) The use of models could increase selfmotivation of nurses intrapersonally to familiarize themselves in implementing the model, 2) Application of the model provided convenience for patients in overcoming the perceived stress, 3) Stages of implementation of the model provided convenience for nurses in helping the stress management as what as patients feel, 4) The description found at each stage of the model implementation makes it easy for the patient to meet his needs, 5) the implementation of the model stage 
performed by the nurse helps the patient find the solution quickly and accurately, 6) the patient feels more appreciated when the nurse apply the model, And 7) Visualization of the model in picture form helps the patient in understanding the actions of the nurse.

Patients are individual who have surrendered themselves to nurses in hospitals, they have many needs: biological, psychological, social, and spiritual. Soft skill model is one of ability that can be used by nurses in order to fulfill patient requirement. The two skills in the soft skills will help nurses to facilitate the needs of their patients

The nurse is a teacher for the patient, referring to Muqowin's opinion (2012: 5) between the four skills then personality skills are intrapersonal skills while social skills are interpersonal skills. The intrapersonal skills of nurses in managing stressaffected patients can be done by looking polite, maintaining personal hygiene, being skilled at managing time, and listening patiently. Interpersonal skills need to be the basis for nurses in managing their patients, can be done through several capabilities of communication skills, ability to cooperate, trained in work ethics, and flexible in duty.

Intrapersonal skills of nurses can be done by referring to several indicators, including acting in accordance with the norms or religions embraced, legal, social, and cultural. Nurses have the skills of respecting patients according to the religion adopted while serving patients both in hospitals and in other health care centers. At the time of carrying out nursing care nurses within the limits of professional authority, so that nurses remain more careful in the application of nursing services. The social aspect needs to be a nurse's consideration in practicing intrapersonal skills, whereby nurses can be more inclusive, objective and non-discriminatory. The culture of the patient makes the nurses understand many people, so that the individual patient's cultural experience will be the basis of the implementation of each care provided.

\section{Effective Model of soft skills training for nurses in managing stress for the patients in the hospital}

The evaluation result explained that the score obtained by the nurse before the training was $46.4 \%$ up to $66 \%$. After given the material about soft skills and stress, the result of the evaluation obtained by the nurse was $71,4 \%$ up to $83,9 \%$, that was in good category and very good. These results showed that through a model designed to improve nurses' ability to perform nursing services to their patients so that the model was effective

The theory conveyed by Person (2011: 15) explains that effective learning is a learning that is able to bring students to achieve learning objectives or competencies as expected. Nurses who had been through the learning process conducted for two days had a better ability than previous abilities, especially for soft skills and stress materials. it was reflected from the results of the tests they had been through.

Tests performed by the nurses were conducted through pre-test and post-test. Before the theory was given the pre-test was done, the nurse scored enough at this stage, and an increasing obtained in the post-test after the material is given with a good average result $(80.4 \%)$. The effectiveness can also be assessed from the completeness of the learning of nurse. As we know (Depdikbud, 1996) each student is said to be complete the learning (individual completeness), if the proportion of answers more than or equal to $65 \%$. This means that individually developed models can be used by nurses, especially in managing stress for patients in the hospital.

\section{References}

[1] Borg,W.R., \& Gall, M. D. Educational Research An Introduction. Boston: Pearson Education Inc. 2003 ( $7^{\text {th }}$ ed).

[2] Burnham, John West. Managing Quality in Schools, Secon Edition. Eastbourne: Printed and Bound by CPI Antony Rowe. 1997.

[3] Carpenito, LJ, Nursing Diagnosis, Application to Clinical Practice. 2000.

[4] Chen, Victoria Febe, Soft Skill For Success series The Good Attitude Skill For Success in Life and Career, Panduan Membawa Diri di Dunia Kerja. Jakarta: PT Bhuana Ilmu Populer. 2012.

[5] , Soft Skill For Success series The Good Attitude Skill For Success in Life and Career, Menciptakan Keharmonisan di Dunia Kerja. Jakarta: PT Bhuana Ilmu Populer. 2012.

[6] Soft Skill For Success series The Good Attitude Skill For Success in Life and Career, Sikap Tepat, Karier Hebat. Jakarta: PT Bhuana Ilmu Populer. 2012.

[7] David Sines, Sharon Aldridge-Bent, Agnes Fanning, Penny Farelly, Kate Poter, and Jane Wright,Community and Public Health Nursing, $5^{\text {th }}$ edition. Willey Blackwell. 2009.

[8] Effendy, Nasrul, Dasar - Dasar Keperawatan Kesehatan Masyarakat. E/2. Jakarta: EGC. 1998.

[9] Elfindri, dkk, Soft Skills Bidan dan Perawat. Jakarta: Baduose Media. 2009.

[10] Elfindri, dkk, Pendidikan Karakter Kerangka, Metode dan Aplikasi Untuk Pendidik Dan Profesional. Jakarta: Baduose Maedia. 2012.

[11] Ford, Andrew, Modeling the Environment. Island Press, Washington D.C. 2009 (2nd edition): 2009 (2nd edition): (http://serc.carleton.edu/introgeo/models/WhatIsAM odel. Html/12/11/2016). 
[12] Gagne, RobertM. The Conditions of Learning, Second Edition. New York: Printed in the United States of America. 2012.

[13] Gregory, Robert J. Psycological Testing: History, Principles and Aplications. Boston: Allyn and Bacon. 2000.

[14] International Journal of Clinical Skills, Effectiveness of Simulation on Promoting Student Nurses Management Skills. London: SE1 2UZ United Kingdom. 2008, Volume 2 Issue 1, ISSN 1753-044X.

[15] Japanese Journal of Quality and Safety in Healthcare. Non-Technical Skills (NTS) for
Enhancing Patient Safety: Achievements and Future Directions. London. 2012.

[16] Joyce, B., and Weil, M. Models of Teaching $\left(4^{\text {th }}\right.$ Edition). Massachusetts: Allyn and Bacon Publisher.1992.

[17] Joyce, Bruce, Marsha Weil, Beverly Showers. Model Of Teaching. USA: Allyn and Bacon. 2000.

[18] Kaipa.P., \& Milus.T. Soft skills are smart skills. (http://kaipagroup.com/2 article/soft skills.pdf.12/07/14). 2005.

[19] Katherine M, Fortinash, Patricia A. Phsychiatric Mental Health Nursing, Fifth Edition. Holoday Weorred. 2012. 